\title{
Analisis Manajemen Pengetahuan Terhadap Performa Organisasi
}

\author{
Alvin Kurnia Rahmansyah*, Asiqotul Khusniyah, Yusuf Amrozi \\ Program Studi Sistem Informasi, Fakultas Sains dan Teknologi, \\ Universitas Islam Negeri Sunan Ampel Surabaya, Surabaya, Indonesia \\ Email: *H96219039@uinsby.ac.id
}

\begin{abstract}
Knowledge management (KM) is still an important topic in the field of management information systems. KM practices have been shown in improving the organizational performance. Therefore, it is important to know how to refine our understanding of knowledge concepts and practices in improving the organizational performance. The first aim of this study is to analyze the management information systems and finds its relationship. Second, KM analysis. Third, analyze organizational performance. Fourth, shows the role between KM and organizational performance that affect such as organizational structure and information technology. The method used is descriptive qualitative research. The results show that KM has a significant effect on organizational performance. The better the use of knowledge management, the better the organizational performance.
\end{abstract}

Keywords: Knowledge management, Management information systems, Organizational performance

\begin{abstract}
Abstrak
Manajemen pengetahuan (KM) masih menjadi topik penting di bidang sistem informasi manajemen. Praktik KM telah terbukti meningkatkan kinerja organisasi. Oleh karena itu, penting untuk meneliti bagaimana menyempurnakan pemahaman tentang konsep dan praktik manajemen pengetahuan untuk meningkatkan kinerja organisasi. Tujuannya ialah, pertama, menganalisis sistem informasi manajemen dan menemukan hubungannya. Kedua, analisis KM. Ketiga, menganalisis kinerja organisasi. Keempat, menunjukkan peran antara KM dan kinerja organisasi yang mempengaruhi, seperti struktur organisasi dan teknologi informasi. Metode yang digunakan ialah penelitian kualitatif deskriptif. Hasil penelitian menunjukkan bahwa KM berpengaruh signifikan terhadap kinerja organisasi. Semakin baik penggunaan knowledge management maka semakin baik pula kinerja organisasi.
\end{abstract}

Kata Kunci: Kinerja organisasi, Manajemen pengetahuan, Sistem informasi manajemen.

\section{Pendahuluan}

Manajemen pengetahuan merupakan suatu rencana untuk menganalisis, mengorganisasikan, dan saling memberitahukan pengalaman sehingga yang satu dapat memetik manfaat dari pengalaman dan pemahaman yang lain. Pengalaman dan pemahaman tersebut bisa diperlihatkan dari suatu individu maupun organisasi. Manajemen pengetahuan berfokus pada bagaimana mendapatkan penemuan baru dari informasi yang masih mentah untuk menjadi data yang bisa dinikmati dan berguna oleh semua pihak setelah menjadi pengetahuan.

Nonaka [1] menyatakan bahwa pengetahuan ialah suatu alat yang intensif dan efektif sehingga dapat meningkatkan kecakapan organisasi untuk melaksanakan perbuatan yang tepat. Untuk mengembangkan potensi manusia yang berdaya saing, dibutuhkan olahan pengetahuan yang sudah dimiliki oleh setiap individu dalam suatu organisasi. Olahan pengetahuan sangat berguna bagi kelangsungan organisasi karena pada dasarnya pergerakan dalam organisasi itu bersumber dari pengetahuan sehingga menjadi organisasi yang kompetitif [2].

Dalam upaya mencapai haluan organisasi, performa individu dan organisasi merupakan salah satu alasan yang penting dalam mencapai tujuan organisasi. Performa individu yang baik bisa 
dipandang dari kualitas, kuantitas, dan ketepatan waktu. Jika performa individu sudah sesuai ukuran yang telah diterapkan sebelumnya maka organisasi akan dengan mudah mencapai tujuan. Selain performa individu, performa organisasi juga merupakan faktor terpenting dalam mencapai tujuan organisasi. Performa organisasi yang baik dapat dilihat dari kinerja keuangan dan kinerja operasional [3].

Sistem informasi merupakan sebuah sistem yang menyajikan informasi untuk kepentingan manajemen dalam mengambil keputusan dan juga untuk menjalankan kegiatan operasional perusahaan. Sistem tersebut merupakan gabungan dari orang-orang, teknologi informasi serta prosedur-prosedur yang tergorganisasi. Pada umumnya sebuah perusahan atau organisasi menyediakan berbagai macam bentuk informasi yang berguna bagi manajemen. Sebagai contoh: Perusahaan toko buku memiiki sistem informasi yang menyajikan informasi tentang buku apa saja yang dijual setiap harinya, dan juga stock buku-buku yang tersedia, dengan informasi tersebut, seorang manajer dapat membuat sekaligus mengambil sebuah keputusan tentang stock buku apa yang harus segera mereka sediakan untuk dijual, manajer juga dapat mengetahui buku apa yang paling dominan untuk dibeli konsumen, sehingga nantinya mereka dapat memutuskan buku tersebut bagaimana jumlah stock dari buku tersebut.

Tujuan utama dari sistem informasi adalah menghasilkan sebuah informasi. Sistem informasi selalu mencakup data-data yang penting, dimana data tersebut diproses sehingga menjadi bentuk yang berguna bagi para manajer ataupun pemakainya. Data yang diproses begitu saja tidak cukup dapat dikategorikan sebagai sebuah informasi. Untuk dapat digunakan, sebuah informasi harus didasari oleh tiga faktor utama sebagai berikut: sesuai kepada pelakunya atau relevan (relevance), tepat waktu (timeliness), dan juga tepat nilainya atau akurat (accurate). Informasi yang tidak didukung oleh tiga faktor utama ini tidak dapat dikaategorikan sebagai informasi yang berguna, namun hal tersebut merupakan sampah (garbage).

Manajemen pengetahuan (knowledge management) secara umum bisa didefinisikan sebagai suatu prosedur yang sistematis dalam mengatur dan memproses nilai intelektual serta berbagai macam bentuk informasi baik berasal dari individu atau organisasi untuk menciptakan kemampuan kompetitif dan meningkatkan sebuah keunggulan dan inovasi. Manajemen pegetahuan memfokuskan diri kepada pengembangan komptensi dan pengetahuan para individu (pelaku organisasi) yang merupakan intangible asset sehingga mereka bisa berinovasi. Manajemen pengetahuan tidak dibatasi pada perangkat teknologi software dan hardware yang merupakan tangible asset [4].

Pengetahuan adalah sesuatu yang lebih bermakna dari pada informasi. Pengetahuan dapat meningkat melalui interaksi dengan informasi. Pengetahuan dibedakan menjadi dua kategori yaitu explicit dan tacit knowledge. Tacit knowledge adalah sebuah kemampuan yang dimiliki seseorang atau sebuah kebiasaan yang ada. Pengetahuan ini sulit untuk dikomunikasikan dan sulit untuk dituangkan ke dalam bentuk lain yang lebih terstruktur. Sedangkan explicit knowledge merupakan pengetahuan yang telah diterjemahkan sehingga pengetahuan ini lebih terstruktur dan bisa disimpan, serta dapat dibagikan ke orang lain dengan mudah. Dalam esensi menajemen pengetahuan diperlukan keduanya sehingga dapat membuat manajemen pengetahuan menjadi semakin luas dan tentunya dapat dibagikan ke seseorang lainnya [5].

Di dalam pelaksanaan manajemen pengetahuan ada tiga hal yang harus diperhatikan yaitu: knowledge creation, dilaksanakan dengan menciptakan sebuah hal baru dan layanan baru, serta dapat pula menciptakan sebuah prosedur baru, proses baru, pekerjaan baru, sistem baru dan peraturanperaturan baru. Hal ini tidak hanya membuat suatu pengetahuan baru tetapi juga mempebaiki proses yang ada; knowledge sharing, memperoleh pengetahuan baru akan menjadi sangat penting agi organisasi, akan tetapi tidak akan mencapai hasil maksimal ketika tidak disebarkan; knowledge utilization yang bisa didefinisikan sebagai knowledge application, hal ini dapat berbentuk document management, groupware, dan e-learning. Berdasarkan tiga hal tersebut secara umum proses manajemen pengetahuan terdiri atas proses penciptaan, penyebaran, penyimpanan dan penerapan, dan juga perlindungan pengetahuan [6].

Secara umum organisasi adalah sebuah kesatuan tempat atau sarana untuk mencapai berbagai macam tujuan. Organisasi mempunyai banyak komponen diantaranya terdapat banyak orang, tata hubungan kerja, spesialis pekerjaan serta kesadaran rasional dari anggota sesuai dengan kemampuan dan spesialisasi anggota masing-masing. Secara singkat organisasi bisa didefinisikan sebagai sebuah 
sistem perkumpulan formal, berstruktur, dan juga terkoordinasi dari sekumpulan orang yang bekerja sama untuk mencapai sebuah tujuan tertentu. Organisasi memiliki tiga unsur penting sehingga organisasi bisa terbentuk dan berjalan. Sekelompok orang, dimana pelaku tersbut yang nantinya bertindak sebagai atasan ataupun bawahan dalam organisasi. Dengan adanya kerja sama tentu akan menghasilkan pembagian hak dan kewajiban serta tanggung jawab. Tujuan yang hendak dicapai, kesepakatan dari orang yang bekerja sama inilah yang menjadi tujuan berorganisasi [7].

Penelitian kualitatif adalah langkah-lagkah untuk mengadakan penelitian dan mengetahui arti yang beberapa individu atau sekelompok orang menganggap berasal dari masalah umum atau kemanusiaan. Artikel ini bersifat deskriptif yang merupakan arti dari data yang terhimpun berbentuk kata-kata yang menjadi kalimat atau gambar sehingga tidak menegaskan pada angka.

Penulisan artikel ini berisi tentang analisis manajemen pengetahuan yang berpengaruh pada performa organisasi dengan harapan agar para manusia memiliki daya saing tinggi dalam manajemen pengetahuan terhadap performa organisasi. Dengan begitu tercapai organisasi yang efektif dan kompetitif. Dengan begitu, artikel ini hendaknya bisa dijadikan petunjuk untuk organisasi dalam mewujudkan sejauh mana manajemen pengatahuan terhadap performa organisasi yang bisa menjadi pengaruh baik bagi organisasi penelitian dalam rangka mengambil tindakan untuk meningkatkan performa organisasi.

\section{Metode}

Penelitian kualitatif selalu mengandung petikan-petikan data yang merupakan fakta yang ditulis di artikel terdahulu guna memberikan sokongan kepada apa yang dikemukakan dalam artikel. Namun fakta dan data yang terkumpul tidak sebagai sebuah bukti ataupun penolakan, melainkan untuk mengumpulkan fakta yang beragam untuk di analisis sehingga menghasilkan kesimpulan yang berarti $[8]$.

Secara mendasar, penelitian kualitatif mempunyai dua arah, yaitu mewujudkan dan mengemukakan, selanjutnya mewujudkan dan menguraikan. Pada intinya, artikel ini memiliki tujuan untuk memperoleh sebuah rangkaian tindakan yang sifatnya umum terhadap kenyataan sosial dari prespektif partisipan. Proses tersebut tidak dapat langsung dipastikan melainkan dianalisis untuk mendapatkan sebuah kesimpulan [9].

\section{Hasil dan Pembahasan}

\section{Sistem Informasi Manajemen}

Informasi merupakan data yang sudah diolah sehingga mempunyai sebuah makna bagi penerima dan mempunyai nilai sehingga berpengaruh kepada keputusan yang akan dibuat. Sumber dari segala informasi sendiri adalah data. Data adalah sebuah fakta yang memberikan gambaran yang luas tentang suatu keadaan. Fungsi dari data yaitu untuk alat bahan dasar yang objektif guna mengolah sebuah keputusan dan kebijaksanaan oleh pimpinan organisasi. Data menjadi sangat bagi manajemen sebab data digunakan dalam berbagai keperluan seperti, pengetahuan, perkiraan, pertimbangan dan keputusan [10].

Sedangkan sistem merupakan sebuah kumpulan dari berbagai macam komponen atau unsurunsur yang terorganisir, saling bergantung dan juga terpadu untuk satu tujuan. Di dalam sistem sangat penting untuk setiap unsur pembentuk di dalam organisasi diperhatikan sehingga nantinya suatu sistem ini dapat bekerja secara maksimal. Di dalam organisasi setiap proses yang dikerjakan oleh bagian dari unsur pembentuk organisasi tersebut dan tetap saling berhubungan akan mengahasilkan sebuah hasil yang efektif [11].

Sistem informasi merupakan sistem yang menyajikan sebuah informasi untuk manajemen guna mengambil keputusan serta sebagai patokan untuk menjalankan organisasi, di mana sistem tersebut adalah gabungan dari orang-orang, teknologi informasi serta prosedur-prosedur yang tergorganisir. Penegelola sistem informasi perlu melaksanakan transformasi informasi yaitu, pengubahan data menjadi informasi yang kemudian disajikan secara statistika atau visual untuk didokumentasikan dan disebarluaskan [12]. 
Pada intinya sistem informasi merupakan suatu sistem di dalam sebuah organisasi yang menghubungkan antara bagian organisasi yang menghasilkan informasi berupa seperti laporan-laporan dengan bagian organisasi yang akan menggunakan informasi dari laporan tersebut. Oleh karena itu, maka sistem informasi mendapat perhatian dari semua organisasi, atau dapat dikatakan penggunaan atau pengelolaan sistem informasi yang baik akan membuat performa organisasi menjadi efektif.

\section{Manajemen Pengetahuan}

Pengetahuan menjadi aset yang penting di dalam organisasi sehingga menjadi kekuatan yang menjadi nyawa organisasi. Di dalam organisasi yang menggunakan pengetahuan merupakan sebuah organisasi yang mempunyai keunggulan bersaing. Keunggulan bersaing tersebut dapat diciptakan dengan memaksimalkan data dan informasi yang dikombinasikan dengan memanfaatkan keterampilan, ide dan motivasi dari anggota organisasi.

Dalam pengetahuan terdapat dua tipe yaitu, pengetahuan implicit (tacit) dan pengetahuan eksplisit (explicit). Pengetahuan implicit merupakan pengetahuan yang masih berada di dalam pikiran seseorang yang memiliki pengetahuan tersebut dan bersifat pribadi. Maka sangat penting agar suatu organisasi untuk mendapatkan, menyebarkan dan memanfaatkan pengetahuan impisit dari setiap anggota organisasi untuk mengoptimalkan penggunaan modal intelektualnya sendiri. Sedangkan pengetahuan eksplisit merupakan pengetahuan yang secara eksplisit terdapat di dalam organisasi. Pengetahuan eksplisit cenderung terstruktur dan refleksi di dalam berbagai macam bahan untuk membuat peraturan dan standar kerja dalam organisasi [13].

Dalam menciptakan pengetahuan di dalam organisasi, terdapat empat pola, yaitu sosialiasi (dari implicit ke implicit),di dalam tahapan ini pengetahuan implicit individu dibagi melalui seuatu pengalaman bersama dalam interaksi sosial untuk mendapatkan pengetahuan tacit baru. Eksternalisasi (dari implicit ke explicit), adalah proses artikulasi dari implicit ke explicit knowledge. Kombinasi (dari explicit ke explicit) proses menggabungkan antara explicit knowledge yang dimiliki oleh seseorang yang berbeda, kemudian diatur ke dalam sistem manajemen pengetahuan. Internalisasi (dari explicit ke implicit) proses untuk meningkatkan pengetahuan sumber daya manusia, yang berarti semua data dan informasi yang telah disimpan dalam organisasi dapat dimengerti dan dimanfaatkan oleh semua anggota organisasi, dan untuk mendapatkan pengetahuan tersebut didapatkan dari media yang ada [4].

Terdapat tiga proses utama dalam knowledge management. Pertama penciptaan pengetahuan, adalah sebuah prosedur untuk menghasilkan pengetahuan. Pengetahuan ini di dapat melalui informasi yang berbentuk pengalaman dan keahlian individu. Kedua adalah penggunaan pengetahuan, yaitu berkaitan dengan pengetahuan berupa perangkat teknis antara lain mesin dan peralatan yang dimanfaatkan untuk peningkatan nilai lebih atau produktivitas. Ketiga adalah berbagi pengetahuan, aktifitas pemindahan pengetahuan dari seseorang ke orang lainnya. Berbagi pengetahuan artinya setiap seseorang mengerti tentang begitu pentingnya pengetahuan untuk perusahaan dan membagi ilmu yang didapat dengan individu yang lain [6].

Tiga proses inilah yang menjadi sangat penting dalam knowledge management. Apabila sebuah kreasi terhadap sebuah inovasi muncul, namun tidak dilakukan proses berbagi pengetahuan, maka hasil dari sebuah inovasi tidak Akan maksimal karena hanya sedikit orang yang mengerjakan hasil inovasi tersebut, apabila muncul sebuah alat teknologi baru namun tidak dibagikan bagaimana cara kerja dan cara penggunaan mesinnya maka alat terseut tidak Akan maksimal.

Dalam knowledge management ada beberpa tantangan yang harus dijawab agar knowledge management bisa berjalan dengan baik. Dalam penerapannya sangat penting untuk bisa membedakan antara dana dan informasi dengan pengetahuan. Apabila sebuah organisasi tidak bisa membedakan keduanya maka data dan inormasi serta pengetahuan akan menjadi tidak bernilai. Keseimbangan antara penciptaan pengetahuan dan berbagi pengetahuan yang harus berimang karena apabila didalam organisasi keduanya tidak seimbang maka penciptaan pengetahuan tidak maksimal dan berpengearuh pada tujuan organisasi. Memangun hubungan saling percaya antara anggota organisasi juga sangat penting, manajemen sumber daya manusia dapat mendorong budaya yang bisa membuat proses berbagi atupun munculnya penciptaan pengetahuan antara anggota organisasi [8] 


\section{Performa Organisasi}

Performa merupakan proses yang dipakai oleh pemimpin untuk menentukan karyawan sudah melakukan tugas dan tanggung jawabnya dengan benar atau belum. Sehingga tahapan yang digunakan sesuai dengan performa yang sedang diamati.

Kaplan dan Norton (1996) memperkenalkan keseimbangan yang menekankan pada semua ukuran keuangan dan tidak keuangannya menjadi bagian sistem informasi untuk para pekerja di semua kedudukan yang ada dalam organisasi.

Rakhmawati (2017) mengungkapkan dalam organisasi diperlukan adanya adopsi pendekatan dan kegiatan-kagiatan yang menunjang dalam mengatasi tantangan di masa depan. Dengan hati-hati dan tepat waktu agar tercipta manajemen pengetahuan yang sukses.

Hasil penelitian yang dilakukan Puryatini (2017) menunjukkan bahwa dukungan empiris berhubungan positif dan penting antara manajemen pengetahuan dan performa organisasi. Manajemn telah ada sebagai sumber dari keunggulan kompetitif yang mendukung keunggulan bersaing hingga mampu menciptakan performa organisasi yang hebat.

\section{Pengaruh Langsung Manajemen Pengetahuan dalam Mendorong Performa Organisasi}

Suatu organisasi akan meningkat efektivitas dan menjadi efisien ketika manajemen pengetahuan mengemukakan suatu perbaikan dengan fokus pada perkembangan dan penggunaan informasi dan penggunaan pengetahuan. Peluang yang ditawarkan manajemen pengetahuan bagi profesional informasi dan perpustakaan untuk menjadikan mereka berguna terhadap organisasi induknya. Dengan apa yang telah mereka lakukan selama ini. Meskipun disekitar manajemen pendidikan masih banyak masalah, tetapi konsep yang dijadikan untuk titik tolak bagi anggota organisasi untuk lebih berperan secara menyeluruh dalam mencadangkan seluruh peluang pengetahuan dan informasi bagi organisasi sehingga mencapai tujuan dengan maksimal.

Telah diketahui varibel inovasi tidak berpengaruh dalam performa, Puryatini et al., (2017) melakukan wawancara dengan salah satu informan di suatu organisasi penelitian pemerintah secara luas dan tersusun. Hasil dari wawancara tersebut sebagai berikut: "persepsi inovasi dengan aparatur sipil negara sebagai pelayan sudah berbeda domain pengelolaan, inovasi muncul karena adanya kebebasan berpikir dan bertindak akan tetapi karena dalam pemerintahan sudah ditetapkan indikatorindikator dan target yang hendak dicapai maka timbul adanya kesenjangan dalam inovasi". "karena ada anggapan bahwa otoritas wewenang sejalan dan searah dengan otoritas inovasi, maka inovasi seringkali bergantung pada individu yang memiliki otoritas wewenang yang memang berkeinginan untuk menghidupkan inovasi itu sendiri".

Hasil dari penelitian Puryatini et al. (2017) nilai loading dari indikator Knowledge management dan Performa organisasi $\geq 0,5$ dengan nilai p-value kurang dari 5\% (signifikan), hal ini berarti pengukuran konstruk Knowledge management dan Performa organisasi telah memenuhi syarat validitas konvergen. Nilai Composite Reliability Coefficients dan Cronbach's Alpha Coefficients dari variabel Knowledge management dan Performa organisasi menunjukkan nilainya lebih dari 0,70 yang berarti variabel Knowledge management dan Performa organisasi adalah reliable. Full colinearity VIF pada variabel Knowledge management dan Performa organisasi kurang dari 3,3 maka dapat dikatakan bahwa model bebas dari masalah kolinearitas vertikal, lateral dan common method bias. Nilai Average Path Coefficient(APC) yang dihasilkan sebesar 0.476 dan signifikan kurang dari 5\%.Nilai Average R-Square (ARS) sebesar 0,226 dan Nilai Average Variance Inflation Factor(AVIF) sama dengan 1 kurang dari 5. Dengan demikian, dapat disimpulkan bahwa goodness of fit model telah terpenuhi. Koefisien jalur yang dihasilkan adalah positif yaitu sebesar 0,476 dengan p-value kurang dari $5 \%$. Hal ini berarti manajemen pengetahuan berpengaruh positif signifikan terhadap performa organisasi yaitu semakin baik manajemen pengetahuan maka performa organisasi semakin baik 


\section{Kesimpulan}

Pengetahuan adalah salah satu aset terpenting yang harus dimanfaatkan oleh organisasi. Apabila pengetahuan dapat digunakan secara maksimal maka organisasi memiliki keunggulan kompetitif sehingga menciptakan performa organisasi yang lebih baik dan memudahkan dalam mencapai tujuan organisasi. Oleh karena itu, manajemen pengetahuan memiliki pengaruh langsung untuk menghasilkan sebuah perubahan pada pengembangan dan pemanfaatan pengetahuan dan informasi sehingga mampu menambah efisensi dan efektivitas suatu perusahaan. Secara garis besar, manajemen pengetahuan menjadi faktor penting terhadap performa organisasi. Semakin baik penggunaan manajemen pengetahuan tentunya performa organisasi juga semakin baik.

\section{Referensi}

[1] Anggito, A., \& Setiawan, J. (2018). Metodologi penelitian kualitatif. CV Jejak (Jejak Publisher).

[2] Barney, J. 1991. Film Resources and Sustained Competitive Advantage. Journal of Management, 17(1).

[3] Indiyati, D. (2014). Pengaruh Budaya Organisasi dan Manajemen Pengetahuan Terhadap Keunggulan Bersaing. Sosiohumaniora, 16(2).

[4] Kaplan, R. S., dan D. P. Norton. 1996. The Balanced Scorecard: Translating Strategy into Action: Harvard Business Press.

[5] Lee, Heesok., Choi, Byounggu(2000). Knowledge Management and Organization Performance, Informs \& Korms.

[6] Praharsi, Y. (2016). Manajemen pengetahuan dan implementasinya dalam organisasi dan perorangan. Jurnal Manajemen Maranatha, 16(1).

[7] Puryantini, Navik., dkk. (2017). Pengaruh Knowledge Management terhadap Performa Organisasi Dimediasi Inovasi di Organisasi Penelitian Pemerintah, Berkala Akuntansi dan Keuangan Indonesia, 2(2).

[8] Rachman, F. (2015). Manajemen Organisasi dan Pengorganisasian dalam Perspektif AL-Qur'an dan Hadith. Ulumuna: Jurnal Studi Keislaman, 1(2).

[9] Rakhmawati, A. (2017). STRATEGI PENGELOLAAN MANAJEMEN PERUSAHAAN (Penerapan Manajemen Pengetahuan Ke Dalam Organisasi). Al-Ghazwah, 1(1).

[10] Sutabri, T. (2012). Konsep sistem informasi. Yogyakarta. Penerbit Andi.

[11] Udin (2016). Implementasi Knowledge Management pada Perguruan Tinggi, Jurnal Administrasi Pendidikan, 23(2).

[12] Welczak, Steven (2008). Knowledge Management and Organizational Learning, The Learning Organization, 15(6).

[13] Wijayanti, Desi Putri., Sundinman, Didi (2017). Pengaruh Knowledge Management terhadap Kinarja Karyawan (Studi Empiris pada PT. SMS Kabupaten Kota Waringin Timur), Jurnal Manajemen, 12(1). 